\title{
Correction to: Food Vendor Beware! On Ordinary Morality and Unhealthy Marketing
}

\section{Tjidde Tempels $^{1,2,3} \cdot$ Vincent $^{B^{\prime}} \mathbf{k}^{3} \cdot$ Marcel Verweij $^{3}$}

Published online: 15 January 2020

(C) The Author(s) 2020

\section{Correction to: Food Ethics (2020) 5:3 \\ https://doi.org/10.1007/s41055-019-00064-2}

The title of the article in the initial online publication was mixed up with copy editing information. The original article has been corrected.

Open Access This article is licensed under a Creative Commons Attribution 4.0 International License, which permits use, sharing, adaptation, distribution and reproduction in any medium or format, as long as you give appropriate credit to the original author(s) and the source, provide a link to the Creative Commons licence, and indicate if changes were made. The images or other third party material in this article are included in the article's Creative Commons licence, unless indicated otherwise in a credit line to the material. If material is not included in the article's Creative Commons licence and your intended use is not permitted by statutory regulation or exceeds the permitted use, you will need to obtain permission directly from the copyright holder. To view a copy of this licence, visit http://creativecommons.org/licenses/by/4.0/.

The online version of the original article can be found at https://doi.org/10.1007/s41055-019-00064-2

Tjidde Tempels

t.tempels@ reflects.ru.nl

Vincent Blok

vincent.blok@wur.nl

Marcel Verweij

marcel.verweij@wur.nl

1 Institute for Management Research, Radboud University, Post Box 9108, 6500 HKNijmegen, The Netherlands

2 Faculty of Philosophy, Theology and Religious Studies, Post Box 9103, 6500 HKNijmegen, The Netherlands

3 School of Social Sciences, Wageningen University, Hollandseweg 1, 6707 KNWageningen, The Netherlands 